\title{
Ewelina Błońska
}

Wszechnica Polska Szkoła Wyższa w Warszawie

\section{MOTYWACJA - PRAWO YERKESA-DODSONA. BADANIA WSTĘPNE}

\begin{abstract}
SUMMARY
Motivation - Yerkes-Dodson law

This article aims to present the results of the research in which the influence of arousal on performing easy and difficult tasks was analyzed. For this purpose, Yerkes-Dodson law was used. There was an assumption that performance increases with physiological or mental arousal but when levels of arousal become too high, performance decreases. The subjects from the experimental group listened to music before they were given an assignment. The subjects from the control group were assigned to do their task without any arousal. The preliminary results partially meet expectations. The results from the experimental group are higher in both difficult and easy tasks than in the control group. However, because the preliminary research was conducted among a small sample of 24 individuals, it is advisable to conduct further research on a larger number of respondents.
\end{abstract}

Key words: motivation, Yerkes-Dodson law, activation, performance

\section{PEЗЮME}

\section{Мотивация - закон Йеркса-Додсона}

В исследовании рассматривается эффект стимуляции на решение легких и трудных задач. Для этого использован закон Йеркса-Додсона. Предполагалось, что уровень реализации зависит от уровня возбуждения и сложности задачи, а уровень возбуждения, оптимальный для легких задач, тем выше, чем сложнее задача. Экспериментальная группа слушала музыку перед решением задачи. Контрольная группа решала задачу без 
стимуляции. Результаты, полученные при исследовании, были ожидаемы. Результаты в экспериментальной группе в обеих задачах (легкой и трудной) были лучше, чем в контрольной группе. Поскольку предварительное исследование было проведено в небольшой группе состоящей из 24 человек, желательно провести дальнейшие исследования на большем числе респондентов.

\section{Wprowadzenie}

Termin motywacja stosowany jest w psychologii do opisu wszelkich mechanizmów odpowiedzialnych za uruchomienie, ukierunkowanie, podtrzymanie i zakończenie zachowania ${ }^{1}$.

Pobudzenie emocjonalne określimy jako chwilowy stan organizmu, charakteryzujący się energetyzacją somatyczną i zmianami świadomości, polegającymi na zwężeniu jej pola. Poziom pobudzenia regulowany jest przez siatkowaty układ aktywizujący i autonomiczny układ nerwowy ${ }^{2}$. Kanadyjski psycholog Donald Olding Hebb sugeruje, że zarówno niski, jak i wysoki poziom pobudzenia nie sprzyja efektywnemu funkcjonowaniu. Jest ono natomiast optymalne przy średnim pobudzeniu. Gdy rośnie aktywność mózgu, przetwarzanie informacji powinno być sprawniejsze ${ }^{3}$. Zdaniem wielu teoretyków jeśli zewnętrzna stymulacja jest zbyt silna i następuje przeciążenie informacyjne systemu, wówczas układ siatkowaty uruchamia mechanizmy niedopuszczające do świadomości podmiotu wszystkich napływających informacji lub też przeorganizowujące i upraszczające ich znaczenie ${ }^{4}$.

Założenie dotyczące krzywoliniowej zależności między poziomem pobudzenia a efektywnością funkcjonowania znalazło liczne potwierdzenia empiryczne w badaniach Epsteina ${ }^{5}$. Jednak istnieją również wyniki badań, które są z nim całkowicie niezgodne np. Näätänen ${ }^{6}$ i Neiss ${ }^{7}$. Jedna z najstarszych propozycji, która

1 W. Łukaszewski, Motywacja w najważniejszych systemach teoretycznych, [w:] Psychologia. Podręcznik akademicki, J. Strelau (red.), Gdańsk 2004, s. 427-440.

2 R. Geen, Human motivation: A social psychological approach, Pacific Grove 1995, s. 203.

3 D. O. Hebb, Podręcznik psychologii, Warszawa 1973, s. 256- 260.

4 W. Łukaszewski, D. Doliński, Mechanizmy leżace u podstaw motywacji, [w:] Psychologia. Podręcznik akademicki, J. Strelau (red.), Gdańsk 2004, s. 441-468.

5 S. Epstein, The stability of behavior: I. On predicting most of the people much of the time, "Journal of Personality and Social Psychology" 1979, nr 37(7), s. 1097-1126.

6 R. Näätänen, The inverted-U relationship between activation and performance: A critical review, [w:] Attention and performance, S. Kornblum (red.), New York 1973, s. 155-174.

7 R. Neiss, Reconceptualizing arousal: Psychobiological states in motor performance, "Psychological Bulletin" 1988, nr 103, s. 345-366. 
dotyczy związku między wielkością pobudzenia a poziomem zadaniowego funkcjonowania organizmu, zawarta jest w prawie Yerkesa-Dodsona ${ }^{8}$, które składa się z dwóch twierdzeń. Pierwsze mówi, iż w miarę wzrostu intensywności pobudzenia, czynność wykonywana jest do określonego poziomu krytycznego coraz lepiej, po czym zaczyna pogarszać się aż do całkowitej dezorganizacji. Drugie zaś, że wspomniany poziom krytyczny jest niższy dla zadań trudnych niż dla zadań łatwych.

Jak twierdzi Philip Zimbardo9 , poziom wykonania zmienia się wraz z motywacją i trudnością zadania. W przypadku zadań łatwych i niezłożonych wyższy poziom motywacji podnosi skuteczność wykonania. Jednak w przypadku zadań trudnych i złożonych optymalny jest niższy poziom motywacji. Umiarkowany poziom motywacji jest zasadniczo najlepszy dla zadań o umiarkowanym stopniu trudności. Wykresy w kształcie odwróconej litery „U” pokazują, iż poziom wykonania jest gorszy zarówno przy motywacji skrajnie niskiej, jak i skrajnie wysokiej.

\section{Hipotezy badawcze}

Hipoteza 1:

Poziom wykonania zmienia się wraz z poziomem pobudzenia i trudnością zadania. Poziom pobudzenia optymalny dla zadań łatwych jest wyższy niż dla zadań trudnych.

\subsection{Zmienne (operacjonalizacje)}

Zmienna zależna:

- efektywność rozwiązania zadania łatwego bądź trudnego po pobudzeniu.

Zmienna niezależna:

- wykonanie zadania łatwego lub trudnego,

- poziom pobudzenia.

\subsection{Osoby badane}

W badaniu wzięły udział 24 osoby (13 kobiet i 11 mężczyzn) w wieku 18-19 lat. Byli to uczniowie maturalnej klasy (profil biologiczno-angielsko-informatyczny) Liceum Ogólnokształcącego im. Marii Dąbrowskiej w Pionkach. Każdą osobę badaną przydzielono na podstawie losowania odpowiednio do grupy eks-

8 W. Łukaszewski, D. Doliński, Mechanizmy leżące u podstaw motywacji, [w:] Psychologia. Podręcznik akademicki, J. Strelau (red.), Gdańsk 2004, s. 441-468.

9 P. G. Zimbardo, Psychologia i życie, Warszawa 1999, s. 443-444. 
perymentalnej lub kontrolnej. Zarówno w grupie eksperymentalnej, jak i kontrolnej znalazło się po 12 osób (w grupie eksperymentalnej - 6 kobiet i 6 mężczyzn, w grupie kontrolnej - 7 kobiet i 5 mężczyzn).

\subsection{Procedura eksperymentalna}

Osoby z grupy eksperymentalnej i kontrolnej miały rozwiązać zadania intelektualne. Połowa $\mathrm{z}$ każdej grupy miała zadanie łatwe, druga zaś zadanie trudne (treść zadań w załączniku). Osoby z grupy eksperymentalnej dodatkowo przed rozwiązywaniem zadania wysłuchały stymulującego fragmentu muzycznego, piosenki zespołu Czerwone Gitary pt. Matura.

\section{Wyniki}

Wyniki uzyskane przez osoby badane w grupie eksperymentalnej i kontrolnej oraz średnie wyniki dla poszczególnych grup, przedstawione są poniżej:

Tabela 1. Wyniki uzyskane przez badanych w grupie eksperymentalnej.

\begin{tabular}{|l|r|}
\hline \multicolumn{2}{|l|}{ Wyniki } \\
\hline zadanie łatwe & $100 \%$ \\
\hline zadanie trudne & $50 \%$ \\
\hline
\end{tabular}

Tabela 2. Wyniki uzyskane przez badanych w grupie kontrolnej.

\begin{tabular}{|l|l|}
\hline \multicolumn{2}{|l|}{ Wyniki } \\
\hline zadanie łatwe & $83 \%$ \\
\hline zadanie trudne & $33 \%$ \\
\hline
\end{tabular}

\section{Wnioski}

W badaniu analizowano wpływ pobudzenia na rozwiązywanie zadań łatwych i trudnych. W tym celu wykorzystano prawo Yerkesa-Dodsona. Założono, iż poziom wykonania zmienia się wraz z poziomem pobudzenia i trudnością zadania, a poziom pobudzenia optymalny dla zadań łatwych jest wyższy niż dla zadań trudnych. Badanym w grupie eksperymentalnej przed rozwiązywaniem zadań dano do wysłuchania fragment muzyczny. Badani w grupie kontrolnej rozwiązywali zadania bez wcześniejszego pobudzenia. Uzyskane w badaniu wyniki po części układają się zgodnie z kierunkiem przewidywań. Wyniki 
Wykres 1. Średnie wyniki dla poszczególnych grup.

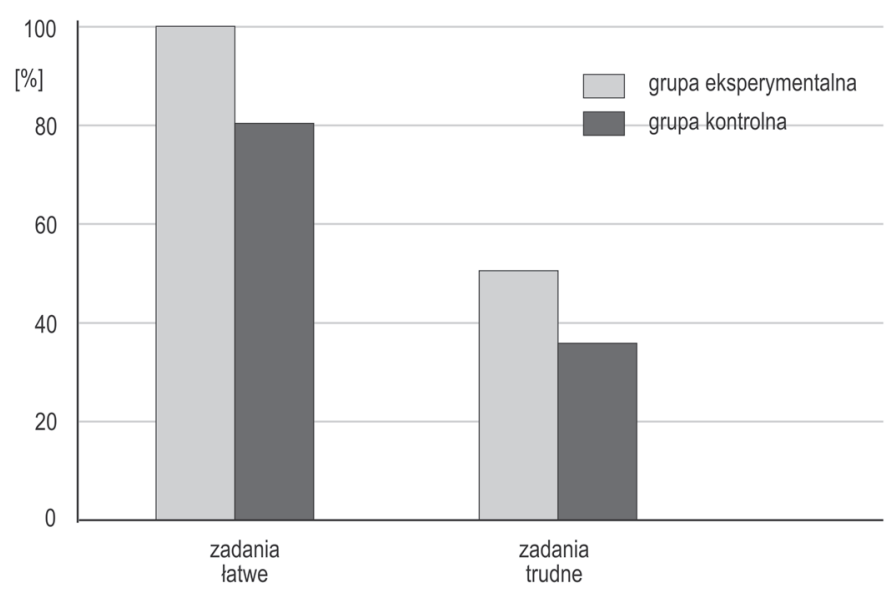

Źródło: badania własne.

w grupie eksperymentalnej w obu zadaniach - i łatwym, i trudnym - były lepsze niż w grupie kontrolnej. Jednakże wnioski z badania mają charakter ograniczony, gdyż badano niewielką liczbę osób i przeprowadzono go tylko w jednej klasie. Utwór był silnie stymulujący, gdyż dla każdego maturzysty przypomnienie o maturze na dwa tygodnie przed egzaminem dojrzałości wywołuje negatywne emocje (było to zauważalne w reakcjach uczniów i w ich wypowiedziach). Prawo Yerkesa-Dodsona mówi, że dla zadań łatwych i nieskomplikowanych wysoki poziom motywacji podnosi skuteczność wykonania - co potwierdziły wyniki badania. Jednak, dla zadań trudnych i złożonych optymalny jest niższy poziom motywacji - co by tu nie miało racji bytu, bowiem przy 'niby' wysokim poziomie motywacji (jak założono, był to utwór silnie stymulujący) skuteczność w rozwiązywaniu zadania trudnego także wzrosła. Czy może ten fragment muzyczny uznać za optymalnie stymulujący, a zadanie trudne, jak i łatwe uznać za zadania umiarkowanie trudne? A może uczniowie, którzy nie słuchali fragmentu muzycznego, nie mieli motywacji do wykonania zadania? I dlatego w grupie eksperymentalnej oba zadania wypadły lepiej? Nie możemy stwierdzić, które z przypuszczeń jest prawdziwe, gdyż wymagałoby to przeprowadzenia dodatkowych badań na większej próbie osób. 


\section{Załączniki}

\section{Zadanie trudne}

\section{ZADANIE}

- - 9 kropek tworzy kwadrat jak na rysunku. Przeprowadź cztery proste przez wszystkie

- . kropki nie odrywając ołówka.

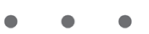

Zadanie łatwe

ZADANIE

Ułóż poniższe wyrazy w kolejności alfabetycznej:

Erognoseologiczny, Lesealizm, Bamflądryga, Weltszmerc, Famdiumądy,

Babomatriarchat, Kompartyment, Wermuje, Chałapudra, Purwykołcie, Kurdypiełki

\section{Literatura}

Epstein S., The stability of behavior: I. On predicting most of the people much of the time, "Journal of Personality and Social Psychology" 1979, nr 37(7).

Geen R., Human motivation: A social psychological approach, Pacific Grove 1995.

Hebb D., Podręcznik psychologii, Warszawa 1973.

Łukaszewski W., Motywacja w najważniejszych systemach teoretycznych, [w:] Psychologia. Podręcznik akademicki, J. Strelau (red.), Gdańsk 2004.

Łukaszewski W., Doliński, D., Mechanizmy leżace u podstaw motywacji, [w:] Psychologia. Podręcznik akademicki, J. Strelau (red.), Gdańsk 2004.

Näätänen R., The inverted-U relationship between activation and performance: A critical review, [w:] Attention and performance, S. Kornblum (red.), New York 1973.

Neiss R., Reconceptualizing arousal: Psychobiological states in motor performance, "Psychological Bulletin" 1988, nr 103, s. 345-366.

Zimbardo P. G., Psychologia i życie, Warszawa 1999. 


\author{
Nina Bycul \\ Uniwersytet w Białymstoku
}

\title{
ОСОБЕННОСТИ АНТРОПОНИМИИ КЛЕТЧИНЫ В ХІХ - НАЧАЛЕ ХХ ВЕКА
}

\author{
SUMMARY \\ Characteristics of anthroponymy of Kleck region \\ from 19th to the beginning of 20th century
}

The subject matter of the article are surnames which appeared in the Wedding Registry as well as in the documentary-historical chronicle of Kleck region. The gathered data show the diversity of etymological sources of anthroponyms with the prevalance of Belorusian linguistic elements. The surnames have typical Belorussian phonetic, word-formative, and semantic elements such as tsyekannye (Cimawiec), dzyekannye (Gordziejczyk), akannye (Makowczuk Makawczuk), yakannye (Jaluga), changing initial [w] into [u] (Ulasień, Ulasiuk). As a result of mutual intertwining of cultures there appeared surnames of different origins such as Polish (Nawrocki), Ukrainian (Kowalczuk), Russian (Popow), Baltic (Bajgus) and Jewish (Mazja).

Key words: linguistic, onomastics, anthroponymy, surnames

\section{STRESZCZENIE}

Osobliwości antroponimii Ziemi Kleckiej w XIX - pocz. XX wieku

Tematem artykułu są nazwiska, które wystąpiły w Księgach kancelaryjnych ślubów oraz w kronice dokumentalno-historycznej Ziemi Kleckiej. Zgromadzony materiał wskazuje na różnorodność źródeł etymologicznych antroponimów z przewagą białoruskich elementów językowych. Nazwiska charakteryzują się obecnością cech fonetycznych, słowotwórczych oraz semantycznych typowych dla języka białoruskiego, np. ciekanie (Cimawiec), dziekanie (Gordziejczyk), akanie (Makowczuk - Makawczuk), jakanie (Jaluga), zamiana początkowego 
[w] na [u] (Ulasień, Ulasiuk). W wyniku wzajemnego przenikania kultur swoje miejsce zaznaczyły nazwiska polskiego (Nawrocki), ukraińskiego (Kowalczuk), rosyjskiego (Popow), bałtyckiego (Bajgus) i żydowskiego (Mazja) pochodzenia.

В древние времена фамилия была сословной привилегией. В первую очередь она присваивалась имущим слоям общества. В России, например, князья и бояре фамилии имели в XIV - середине XVI - XVII веков, духовные служители в XVIII - начале XIX веков. В то время миллионы крепостных крестьян были бесфамильными даже в середине XIX века. У белорусов фамилии (прозвища) появились в XVII - XVIII веках ${ }^{1}$. Формирование и установление понятия фамилия окончательно завершилось во II половине XIX - начале XX веков. Становление фамилий надо рассматривать не как законодательный акт, который установил и утвердил их, а как длительный процесс, вызванный общественной необходимостью.

Личные наименования до сих пор остаются одной из наименее исследованных областей лексического состава белорусского языка, а ведь они являются одним из наиболее важных источников изучения лексики и словообразования языка предыдущих эпох, источником высокой достоверности при изучении онимов ${ }^{2}$.

На начальном этапе своего становления белорусская ономастика развивалась как историко-этнографическо-географическая наука ${ }^{3}$. Системный научный характер изучение собственных имён приобрело в 70-80-ые годы $\mathrm{XX}$ века. В последние десятилетия появилось множество публикаций, посвящённых изучению белорусской антропонимии, создан огромный цикл работ, монографий по восточнославянской ойконимии, исследованиям по конкретным словообразовательным типам ойконимов, но ещё слишком рано говорить о полном системном изучении ономастической системы Беларуси.

В данной статье речь пойдёт о личных наименованиях (фамилиях) жителей города Клецка ${ }^{4}$ и некоторых деревень Клецкого района ${ }^{5}$, антропонимический состав которых довольно разнообразен. Особую группу

1 В. П. Лемтюгова, Фамилия как привилегия, [w:] „Беларусь Сегодня”, №180, www.familii.com. ua/new26.htm [dostęp: 28.10.2013].

2 М. В. Бірыла, Беларуская антрапанімія, t. 1, Мінск 1966, s. 4.

3 В. П. Лемцюгова, Гісторыя анамастыкі, [w:] Stowiańska onomastyka. Encyklopedia, t. 1, E. Rzetelska-Feleszko, A. Cieślikowa (red.), Warszawa-Kraków 2002, s. 17.

4 Город, центр Клецкого района на реке Лань. Расположен в 140 км к юго-западу от Минска (zob. Больщой Белорусский энииклопедический словарь, Т. В. Белов (red.), Минск 2011).

5 Zob. Минская область. Энциклопедия, Л. Ф. Крупец, Г. П. Пашков (red.), Минск 2007. 
составляют фамилии, в которых прослеживаются элементы, характерные для восточнославянских языков, а в частности для белорусского. Мы обратились к белорусским, русским, польским словарям, чтобы подтвердить наши наблюдения, и проанализировали их с учётом восточнославянских, а также и невосточнославянских языковых элементов.

Антропонимический материал для анализа взят из канцелярской книги брачных записей ${ }^{6}$ Арино-Покровской церкви ${ }^{7}$ (1843-1857), а также из документально-исторической хроники Клецкого района «Память» (1999) 8

Археологические данные свидетельствуют, что в Х веке на месте Клецка возникло неукреплённое поселение. Оно исполняло роль административного центра дреговичского населения, которое проживало в верховьях Лани и Уши. Построение дединца и окружающего его города, развитие ремесла и торговли преобразовали Клецк в типичный древний восточнославянский город ${ }^{9}$.

Город Клецк впервые упоминается в 1127 году (летопис. Кльчьскъ, Клечьскъ), расположен на юго-западе Минской области ${ }^{10}$. В летописи Клецк назван дреговичским городом, входящим в состав Туровско-Пинского княжества. В XII веке из состава княжества выделилось Клецкое удельное княжество.

Точной даты вхождения города в состав Великого Княжества Литовского $^{11}$ (в дальнейшем ВКЛ), к сожалению, неизвестно. Но в «Списке русских городов дальних и ближних», составленном в конце XIV - начале XV вв., имеется упоминание о городе: «А се (грады) Литовскыи: Случеск. Городеи, на Немне. Мереч. Клеческ. Кернов. Ковно. [...]. Вильно...». Значит, что уже в это время Клецк находился в составе ВКЛ. До 1442 года Клецк и его окрестности являлись собственностью великого князя литовского. Клецкий повет (волость) охватывал в позднем средневековье огромную территорию, которая значительно превосходила размеры сегодняшнего Клецкого района.

6 Оригинальное название звучит Книга брачныхъ обысковъ Арино-Покровской церкови.

7 Сегодня церковь носит название Храм Покрова Пресвятой Богородицы, Покровская (Вознесенская) церковь, zob. www.kletsk.minsk-region.by/ru/region/religion [dostęp: 01.11.13].

8 Историко-документальная хроника Клеикого района «Память», М. С. Кусенков (red.), Минск 1999. Это книга, в которой на основе архивных документов и материалов, статей и публикаций, воспоминаний непосредственных участников событий рассказано об истории Клецка и Клецкого района.

9 Там же, s. 25.

10 Там же, s. 18.

11 Там же, s. 33. 
В 1502 году жители Клецка впервые узнали крымскую опасность. Татары лютовали в окрестностях Несвижа, Койданова (теперь Дзержинск). Они сожгли Клецк и все его деревянные оборонительные сооружения, так называемый Дольный замок. Следующее нападение татар на Беларусь и Литву произошло в 1506 году, в тот момент в г. Лида проходил сойм ВКЛ, где присутствовали важнейшие магнаты государства, дворянство, а также и сам польский король и великий литовский князь Александр. В 1506 году под командованием М. Л. Глинского под Клецком на Красноставе произошло жуткое сражение, после которого набеги на Клецкие земли прекратились. Была одержана победа над крымскими татарами ${ }^{12}$.

С 1523 г. Клецкое княжество находилось во владении королевы Боны Сфорца - жены польского короля, великого князя литовского Сигизмунда Старшего (1506-1548). В Клецке королева показала себя заботливой хозяйкой и отличнейшим реформатором. С её именем связаны попытки создать новые формы землепользования и землевладения в ВКЛ, Русском и Жомойдском княжествах. Впервые такой эксперимент прошёл на территории Пинского и Клецкого княжеств в 1552-1555 гг. С 1557 года город становится собственностью Радзивиллов, создавших здесь Клецкую ординацию - неотчуждаемое феодальное владение.

В 1652 году Клецк получил Магдебургское право. Вторая половина XVI - первая половина XVII веков были временем расцвета производства, торговли и социальных отношений в городе. Социально-экономический подъём стимулировал и развитие образования и культуры.

B XVII веке обострилось религиозное противостояние: между православными с одной стороны и католиками и униатами с другой. В 1626 году в самом Клецке было две униатские церкви. Приход греко-католической церкви составлял половину жителей города и семи окрестных деревень. Католикам принадлежал Троицкий храм (бывший кальвинистский). Имели свой молитвенный дом татары, а евреи - синагогу.

Первые сведения о еврейской общине Клецка встречаются в Законе княжества Литовского от 1529 года. На протяжении 1654-1655 гг. царь Алексей Михайлович захватил ВКЛ. В Клецке был сожжён замок и множество городских зданий. После окончания войны в 1667 году (война между Речью Посполитой и Россией) - город опустошен и разграблен. Изменился и национальный состав города. Радзивиллы, желая как можно скорее восстановить Клецк, приглашали еврейских торговцев, давали им право на держание торговых рядов и лавок, что в дальнейшем способствовало значительному росту еврейского населения в городе.

12 Там же, s. 36. 
В 1793 г. после 2-го раздела Речи Посполитой город примыкает к Российской империи. С 1921 по 1939 гг. территория района оказалась в составе Польши, а с сентября 1939 года вошла в состав БССР.

Культура на территории сегодняшнего Клецка развивалась под воздействием взаимосвязанных социально-экономических, сословно-классовых и политических факторов, опираясь на богатое древнерусское наследие и западные традиции. Она имела типичные черты общности восточнославянских и европейских культур. Основные этнические особенности материальной и духовной культуры определились в XIII-XVI веках, когда в результате широкого поля взаимодействия русской, литовской, польской, еврейской культур возникла единая метакультура, чему способствовали исторические события, а также культурная и языковая близость. Естественное взаимодействие культур создало единое культурное пространство. В настоящее время на территории Клецка и Клецкого района проживает население, разговаривающее на двух языках: русском и белорусском. Оба языка являются государственными.

Антропонимическая система региона отражает богатую событиями историю политической и культурной жизни страны. Древнейший слой хранит в себе слой сильного польского влияния, более современные фамилии обладают рядом черт, характерных для русской модели. Белорусские фамилии схожи с украинскими, прослеживается балтийское влияние. На данной территории получили распространение еврейские фамилии. В результате такого разностороннего взаимодействия сформировалась и разнообразная антропонимическая система ${ }^{13}$.

Антропонимия наиболее из всех частей ономастики подвержена влиянию общественно-политических факторов, более, чем другие уровни языка отражает изменения, которые переживает общество.

Изучению личных наименований данного региона был посвящён ряд публикаций и статей Н. В. Бирилло ${ }^{14}$. По его инициативе была создана фундаментальная картотека различных классов онимов, включающая антропонимию древнебелорусских памятников письменности, современных фамилий. Рамки исследования его работ хронологически ограничены (XV-XVIII вв.), но охватывают все этапы формирования белорусской антропонимической системы, начиная от её зарождения на базе антропонимической системы, сложившейся в процессе общей восточнославянской письменной практики

13 Б. О. Унбегаун, Русские фамилии, Москва 1989, s. 228.

14 М. В. Бірыла, Беларуская антрапанімія, t. 1-3, Мінск 1966-1982; М. В. Бірыла, Тыпалогія і геаграббія славянскіх прозвішчаў, Мінск 1988; М. В. Бірыла, Беларускія антрапанімічныя назвы у адносінах да назваў іншых славянскіх моў, Мінск 1963. 
предыдущей эпохи, и заканчивая уже её относительно сформировавшимся состоянием, когда она приобрела черты современной антропонимической системы.

Лингвистический анализ названий населённых пунктов Минской области был проведён В. П. Лемтюговой ${ }^{15}$. Автор, одна из первых, предоставила официальные формы ойконимов на белорусском языке, были отмечены и проанализированы практически все специфические для Беларуси типы названий населённых пунктов как со стороны лексико-семантического состава их основ, так и со стороны словообразовательных средств.

Поскольку фамилии на исследуемой нами территории в своём большинстве белорусского происхождения, и очень часто встречаются в русифицированной форме, то для более ясной картины описываемых нами антропонимов, целесообразно проанализировать их не только на семантическом и словообразовательном уровнях, но также фонетическом. Надо помнить, что несколько языковых явлений могут выступать в одном антропониме.

Оформление различного рода официальных документов уже в XVI-XVII вв. требовало развёрнутой идентификации пица. Это был период бурного развития деловой письменности, когда наряду с традиционными формами использовались новые формы, характерные для разговорнобытовой сферы. В юридических актах довольно регулярно встречались двух-, трёх-, а изредка, четырёхкомпонентные наименования. В двухкомпонентном наименовании на первом месте обычно стояло мужское личное имя (христианское или дохристианское, славянское), а на втором - компонент с дополнительной информацией о лице: имя от отца, название места проживания или владения, а также другое апеллятивное имя - прозвище. В трёхкомпонентном - в качестве третьего элемента выступала фамилия от деда (как правило, в форме родительного падежа), имя-прозвище или прилагательное на -ский оттопонимического происхождения. Четырёхкомпонентные наименования формировались из того же набора элементов, но отличались только их количественным составом и порядком размещения ${ }^{16}$.

В книге Брачных обысковъ мы прослеживаем не только двух- и трёхкомпонентные наименования жителей, но к тому же к ним добавлено определение сословия каждого лица, а иногда даже имя и фамилия помещика или князя, которому они принадлежали:

15 В. П. Лемцюгова, Беларуская айканімія, Мінск 1970.

16 В. П. Лемцюгова, Антрапанімія II - Прозвішчь, [w:] Słowiańska onomastyka. Encyklopedia, t. 1, E. Rzetelska-Feleszko, A. Cieślikowa (red.), Kraków 2002, s. 436. 
дворянин Иосифг Пилиповъ Крьжновски; Людвига Матеевна Жуковская дворянка; Эмилия Фабиянова Хелмовска дворянка; звонарь Николай Игнатовъ Янушевичъ; мещзанин Иванъ Фёдоровъ Новицки; Анна Андреевна Панкратовичовна мещанка; крестьянин Помещика Обуховича, Василий Романовъ Хилимонъ; крестьянка того же Помещика Анна Василева Сёмуха; крестьянин Князя Льва Радзивилла Дамиан Дмитриевъ Костюкъ; крестьянка того же Князя Өедора Василева Карась; отставной солдат Демиянъ Михайловъ Калевичъ; однодворка Өекла Шишовна.

Исследуя собранный лексический материал на семантическом уровне, следует отметить, что преобладающее большинство личных наименований берут своё начало от апеллятивной лексики. В зависимости от степени мотивированности образующих основ, можем разделить их на две подгруппы ${ }^{17}$ :

1) фамилии, образованные от апеллятивов, значение которых никаким образом не характеризует человека непосредственно, а только в переносном значении;

2) фамилии, образованные от апеллятивов, обозначающие личность по какой-либо примете.

Для образования фамилий первой подгруппы в качестве образующих основ послужили:

- названия домашних животных: Кабанов;

- названия диких зверей и грызунов: Волчок, Заяи, Лис, Оленин;

- названия членистоногих (насекомых): Абабурко (мокрица), Жук, Мотоль;

- названия диких птиц: Ботян, Ворона, Голуб, Голубович, Кажан, Кулик, Соловьёв, Сорокин, Чижик;

- названия рыб: Акула, Бобырь (Пескарь), Карась, Карпович, Плотка, Сазан;

- название частей тела человека и других живых существ, названий покрова тела: Брушкевич, Бородич, Губчик, Каленик, Кишко, Лобко, Пальчик, Рогальчук;

17 Классификация имён с точки зрения мотивированности образующих основ приводится по классификации Н. В. Бирилло (zob. М. В. Бірыла, Беларускія антрапанімічнья..., Мінск 1963, s. 8-12). 
- название растений: Бобик, Бурак, Грибок, Салата;

- название частей и плодов растений: Бересневич, Бобко, Ботвинко, Клос, Корень, Шипула;

- название простых орудий туда, предметов быта и их частей: Булавка, Гвозд, Гвоздзь, Клевеи, Коробкин, Косарь, Крииук, Кульбака, Кульченко, Лучинка, Лямиева, Ситкин, Смолич, Скриба, Товкач, Ярмак;

- названия продуктов питания: Блинеи, Вареник, Кисель, Кулеш, Мурин, Солодушчанко;

- названия денежных единиц: Рублёв;

- название обрядов или праздников: Коляда, Сёмуха.

Для образования фамилий второй подгруппы в качестве образующих основ послужили названия, указывающие на:

- профессию или занятие, статус социальной группы: Гайдукевич, Драгун, Гончаренко, Кравчук, Король, Немера, Новик, Попов, Попок, Слесарев, Шавчук, Шевчук, Шклярик, Царь;

- отношение родства или положение в семье: Близнюк, Ждан, Жданюк, Жданович, Единюк, Мамчии, Правнукова, Сёмуха, Шестак, Шостак;

- внешний вид: Белак, Горбунович, Горбач, Горбук, Кныши, Комяк, Косабуикки, Куикко, Лобочкий, Левшик, Лобыревич, Малевич, Малышко, Мордас, Мордасевич, Птешко, Пьжиков, Суханович, Щерба;

- особенности характера: Пильневич, Лютко, Молчан, Негра, Неверовна, Шабун;

- умственные и физические качества: Буркун, Неплях, Плакса;

- название народа или этническую группу: Жомойдзик, Кашуба, Литвин, Лях, Полешук, Рус, Русак, Русинович;

- название лица по топографической примете: Заблоикий, Нагорныци, Островский.

Христианская церковь, канонизируя святых, канонизировала и их имена, настойчиво и последовательно распространяла их на те народы, куда расширялось христианство ${ }^{18}$. Огромное количество из них и легло в основу фамилий.

Полные имена в функции фамилии обычно использовались в такой форме, в какой они утвердились в языке, официальные и разговорные:

Евтух (церк. Евтихий), Нестер (церк. Нестор), Сазон (церк. Созонт), Сидор (церк. Исидор), Сьмон (церк. Симеон), Хилимон (церк. Филимон), Абрамович (церк. Авраам), Авдеенко (церк. Авдй), Алексейчик (церк. Алексей), Алехнович (церк. Александр),

18 М. В. Бірыла, Беларуская антрапанімія, t. 3, Мінск 1982, s. 3. 
Алешкевич (церк. Алексей), Антонович (церк. Антоний), Астапов (церк. Евстафий), Бартошевич (церк. Варболомей), Васильев (церк. Василиц̆), Гордейчик (церк. Гордий), Грицель (церк. Григорий), Грицкевич (церк. Григорий), Данисевич (церк. Дионисий), Дашкевич (церк. Даниил), Захарчук (церк. Захария), Кононович (церк. Конон), Костюк (церк. Константин), Костюкевич (церк. Константин), Лавринович(церк. Лаврентий), Леонович(церк. Леонт), Леончик (церк. Микулич (церк. Николай), Мойсейчик (церк. Моисей), Николаевич (церк. Николай), Нупрейчик (церк. Онуфрий), Панкратович (церк. Панкратий), Петкевич (церк. Петр), Петрачков (церк. Петр), Пилипович (церк. Филипn), Романович (церк. Роман), Савостей (церк. Севастиан), Савош (церк. Севастиан), Семашко (церк. Симеон), Семенчик (церк. Симеон), Стёпкин (церк. Стефан), Тимовеи (церк. Тимофей), Томчук (церк. Фома), Филиппова (церк. Филипп), Хведюк (церк. Феодор), Хомич (церк. Фома), Шиман (церк. Симон), Ючкевич (церк. Евфимий), Язэпчик (церк. Иосиф), Якимович (церк. Иоаким), Янушевич (церк. Иоанн), Яськевич (церк. Иоанн).

Исследуемый материал показывает нам, что в основу многих фамилий легли христианские имена, как православные, так и католические, а мотивирующими основами послужили и официальные, и разговорные формы имён.

Проанализировав антропонимический состав наименований на словообразовательном уровне, мы проследили следующие факты. Согласно утверждению А. Устинович, формы на -вич, -евии ещё в XV-XVIII вв. не являлись фамилиями в нашем современном понимании, как правило, они выступали в качестве имени по отцу, иначе отчества. Формы фамилий на -ович, -евич в Великом княжестве Литовском имели представители всех сословий общества ${ }^{19}$, несмотря на то, что окончание -ович, -евич было однако привилегией лиц высших сословий:

Антонб Якимовь Масулевичв (крестьянин); Ксаверій Гавріловъ Якимовичь (мещанин); Анна АндрееваПанкратовичовна (мещанка); Кондрать Фёдоровъ Апанасевичв (крестьянин); Анна Амелиянова Страцкевичовна (крестьянка); Николай Игнатовъ Янушевичь (звонарь); Алексей Романовъ Афанасевичв (крестьянин); Марианна Иванова Романовичовна (крестьянка); Фёдор Романовъ Сазановичв (крестьянин).

19 В. Шур, Беларускія ўласныя імёны, Мінск 1998, s. 58. 
Исследователи отмечают, что фамилии на -еня являются специфическими только для белорусской антропонимической системы. Антропонимы с такими суффиксами возникли для обозначения прежде всего детей от имён их родителей ${ }^{20}$ :

Иван - Иваненя, то есть сын Ивана, Жданеня, Зданеня, Кондратеня.

Продуктивными и типичными для белорусской ономастики являются фамилии, образованные от личных канонических имён при помощи суффиксов -чик, -ик, -еи:

Алексейчик, Гордзейчик, Кипрейчик, Куприянчик, Леончик, Мойсейчик,

Нупрейчик, Семенчик, Хведчик, Язэпчик, Ярмольчик; Игнатик, Ярмолик, Тимовеи.

Фамилии на -ский (-ская), -ияий (-икая) имеют топонимический характер, то есть образованы путём субстантивации прилагательных. Основы с такими суффиксами указывают на местность или владение, принадлежащее человеку, или на место происхождения данного лица. Под влиянием польского языка наименования на -ский (-ская), -икий (-цкая) стали образовываться и от личных имён:

Азовский, Беганский, Березовский, Борковский, Борщевский, Ботинский, Бурковский, Василевская, Гавронская, Гзовский, Голевский, Гощинский, Дучинский, Дылевский, Жарновский, Жиевский, Жуковский, Заблочкий, Ковальский, Козловский, Колосовский, Комаровский, Крупский, Кулаковский, Куликовский, Кучински, Лемковский, Лещинский, Лисовский, Лучиикий, Лущицкая, Макрецкий, Малишевский, Масловская, Михайловский, Навроикий, Островский, Пилеикий, Плосковиикий, Раевский, Ратомский, Рачевская, Силиикий, Соколовский, Томашевский, Тупальский, Хвалевский, Хелмовска, Хилинский, Хмелевский, Чижевский, Шавлинский, Щепанский, Якубовский, Ясинский.

B XVI-XVII вв. историческое и культурное развитие Украины проходило в тесной связи с Беларусью (обе входили в состав ВКЛ) ${ }^{21}$. Украинский след можем пронаблюдать в антропонимах, оформленных суффиксами $-y \kappa(-ю \kappa),-ч y \kappa:$

Близнюк, Горбук, Грибок-Ляпчук, Единюк, Жданюк, Захарчук, Зданюк, Ковальчук, Костюк, Кравчук, Крииук, Лукьянчук, Макавчук, Маковчук, Павлюк, Полешук, Рогальчук, Романчук, Семенчук, Томчук, Уласюк, Хведюк, Шавчук, Шевчук.

20 Там же, s. 58.

21 Б. О. Унбегаун, Русские фамилии, Москва 1989, s. 201. 
C середины XVI века подавляющее большинство фамилий усвоило застывшие притяжательные суффиксы -ов, -ев и -ин. Это преимущественно русский тип фамилий: Астапов, Васильев, Гостеев, Дубров, Ермолаев, Жданов, Кабанов, Климова, Кондратьев, Лямиева, Периухов, Петрачков, Попов, Пьжиков, Романов, Рублёв, Сигаров, Слесарев, Соловьёв, Филипова, Шмаков, Березин, Коробкин, Литвин, Мурин, Оленин, Ситкин, Сорокин, Стёпкин.

Идентификация женщин Клетчины заслуживает особого внимания. Наименования лиц женского пола в деловых документах XVI-XVIII вв. являлись редкостью. Объяснялось это бесправием женщины в то время, полной экономически-хозяйственной, юридической и личной зависимостью её в добрачный период от отца, а послебрачный - от мужа. В роли юридического лица в то время женщина могла выступать только в двух случаях: если в семье не было лиц мужского пола (отца, мужа), а также если женщина являлась ответчиком или истцом в судебном деле ${ }^{22}$. Характерная особенность наименований лиц женского пола - это малая доля оценочных форм, минимальное количество в их составе имён-прозвищ дохристианского, славянского происхождения.

Обычно к женскому имени добавлялось имя отца, оформленное суффиксами -овна, -евна или имя мужа, оформленное суффиксами -иха, -овая, -евая, реже -ова, -ева:

Абрамовичовна, Апанасевичовна, Батуровна, Близнюкова, Бобковна, Букатовна, Гриикевичовна, Драгунова, Кишковна, Климова, Корнева, Косаревна, Кравчукова, Куликовна, Кульбаковна, Лев-иикова, Леончиковна, Литвиновна, Мовчанова, Мордасовна, Мордасевичова, $\mathrm{He-}$ веровна, Немеровна, Новиковна, Пашкевичовна, Плаксовна, Поливодовна, Попкова, Роубова, Рогальчуковна, Романо-ва, Романовичовна, Рублёва, Русакова, Сазанова, Семашкевна, Солнцевичовна, Страцкевичовна, Товкачовна, Чижиковна, Шавчу-ковна, Шибковна, Шилова, Шишовна, Шкляриковна, Шостаковна, Батураиха, Дучиниха, Неньковиха, Хилимониха, Шабуниха, Роубае-вая.

В книге Брачных обысковъ (1843-1857) отмечены фамилии невест, оформленные суффиксами -иха, -евая, -ова, -ева свидетельствуют о том, что эти женщины уже были ранее замужем.

Типичные для белорусского языка фонетические явления прослеживаются в нижеследующих примерах антропонимов:

22 В. П. Лемцюгова, Антрапанімія II... , s. 437. 
- замена начального согласного [в] на [у]: Власий - Уласень, Уласюк;

- использование согласных [ח], [x] и сочетания [хв] соответственно согласному [ф]: Феодор - Хведюк, Хведчик; Филимон - Хилимон;

- мягкие согласные, соответствующие твёрдым [д] и [т], произносятся как [дзь], [ць], чем они отличаются от русских [дь] и [ть $]^{23}:$ Бурбуць, Гвоздзь, Гордзейчик, Жомойдзик, Игнацік (Игнатик), Мариінкевич;

- особенностью белорусского языка является наличие твёрдых губных согласных [п],[б],[м],[в],[ф]: Голуб;

- в неударных слогах наблюдаем фонетический процесс аканья ${ }^{24}$ : Лабажевич - Лобажевич, Макавчук - Маковчук, Кароль;

- совпадение гласных [o] и [e] с гласным ['a] по звучанию в неударных слогах после мягких согласных или в начале слова (яканье $\left.{ }^{25}\right)$ : Ялуга, Ярмак.

Заметный след в антропонимии региона Клецкого района оставил польский язык. В русском и белорусском языках ассимилировались апеллятивы и некоторые производные от них фамилии:

Ботян (pol. bocian, бел.бусел, баиян), Гзовский (pol. giеz, бел. авадзень), Гавронская (pol. gawron, бел. грак), Пшепюрко (pol. przepiórka, бел. перапёлка), Клос (pol. kłos, бел. колас).

Несмотря на сильную взаимосвязанность польских и белорусских фамилий ряд фонетических черт подчёркивает польское происхождение. Отличительные польские фонетические признаки:

a) перед $\boldsymbol{e}, \boldsymbol{i}$ и в некоторых других позициях $\boldsymbol{r}$ в результате палатализации даёт звук, который в польском передаётся сочетанием $r z$, а произносится как [்̇]: Коржаневский (Korzeniewski < korzeń 'корень').

23 Мягкие согласные, соответствующие твёрдым [д] и [т] в белорусском языке, произносятся как [дзь] и [ць], чем они существенно отличаются от [дь] и [ть]. Такое произношение получило название дзеканья и цеканья. Русская речь многих белоруссов сохраняет эту черту, и по ней носители русского языка узнают их белорусское происхождение. Zob. A. А. Кривицкий, А. И. Подлужный, Учебник белорусского языка, Минск 1994, s. 56.

24 В белорусском языке в неударных слогах количество различных гласных уменьшается, они произносятся несколько короче, но ясность их звука сохраняется. Уменьшение количества гласных вызывается аканьем, в результате которого [о] и [э] после твёрдых согласных, когда с них смещается ударение, произносится как [a]. Zob. A. А. Кривицкий, А. И. Подлужный, Учебник..., s. 15-16.

25 Совпадение гласных [о] и [е] с гласным [a] по звучанию в неударных слогах после мягких согласных получило название яканья. Яканье характеризует манеру произношения, но в его основе лежит название буквы я. Zob. A. А. Кривицкий, А. И. Подлужный, Учебник..., Минск 1994, s. 22-23. 
б) русские, белорусские -оро-, -оло-, -ере- между согласными параллельны польским ro, to, rze (<re):Навроикий (Nawrocki < nawrócić 'возвратиться').

Встречаются также некоторые фамилии, которые по лексическим, морфологическим и историческим признакам должны считаться польскими, что подтверждает типичный польский формант -ski //-ska:

Лещзинский (Leszczyński < leszczyna 'ореховое дерево'), Гзовски, Пилецьки, Новиики, Кучински, Кучинска, Косабуияки, Косабуияка, Раевска, Хелмовска.

Обратимся к фамилиям литовского происхождения. В антропонимическом составе данного региона нами зафиксированы следующие образцы:

Байгус от лит. ап. baiga, baigti 'окончить, перестать'; Бурбуть (Бурбуцьв) от лит. антр. Burba = ап. burba 'тот, кто много говорит, болтун', burbeti, burbesti 'грохотать, тарахтеть', от лат. Burbis = ап. burbis 'тот, кто быстро говорит'; Довнар-Зенькович от лит. им. Daūnoras < Daugnōra(s). В лит. именн. дв. Daūnoras, 1. Dau- < Daug(:daūg 'много'), 2. -nor-as (:noreti, nóras 'хотеть; желать' $)^{26}$.

Следует отметить особую группу фамилий в антропонимическом составе Клетчины - это еврейские фамилии. По характеру своего происхождения они весьма разнообразны:

Мазия, Мазье от др.-евр.им. Маzіа, Mazya (Moche); Периухов от библ. им. Peres; Шмулевич от др.-евр. им. Szemuel, Szmuel, Samuel 'Шмуль', 'Эль его имя'구 Рабион от ап. рабин 'служитель культуры в еврейской религиозной общине ${ }^{28}$; Файнберг от нем. ап. fein 'дробный, деликатный', ср. польск. ап. fajny; от нем. ап. Berg 'гора', Шnигель от нем. ап. Spiegel 'зеркало', 'производитель или продавец зеркал'. Некоторые фамилии сохранили своё первоначальное обличие (Мазия, Мазье, Шпигель), а часть адаптировалась согласно моделям славянских фамилий ( Периухов, Шмулевич).

На формирование и становление антропонимического состава Клетчины повлиял ряд исторических событий, взаимодействие культур близ лежащих народов, в результате чего воздействие взаимосвязанных

26 Толкование имён см. M. Kondratiuk, Nazwiska pochodzenia bałtyckiego, cz. 1, „Acta Baltico-Slavica”, Warszawa 2000, s. 123.

27 Толкование имён см. Z. Abramowicz, Słownik etymologiczny nazwisk Żydów białostockich, Białystok 2003; Z. Abramowicz, Antroponimia Żydów białostockich, Białystok 2010.

28 Тлумачальны слоўнік беларускай літаратурнай мовы, I. М. Бунчук, М. Н. Крыўко (red.), Мінск 2002. 
социально-экономических, сословно-классовых и политических факторов развития привело к возникновению различных групп антропонимов.

История труда и быта оставила след в фамилиях, лексические основы которых означали социальные отношения, предметы одежды, питания, обычаи и обряды. Многие фамилии рассказывают о былых суевериях. Они являются драгоценными памятниками народных воззрений далёкого прошлого, народного творчества. Немало могут рассказать и об истории языка. Фамилия - слово, и как слово оно составляет неотъемлемую часть языка и подчиняется его законам ${ }^{29}$.

\section{Сокращения:}

$\begin{array}{ll}\text { антр. } & - \text { антропоним } \\ \text { ap. } & \text { - apelatyw } \\ \text { ап. } & - \text { апеллятив } \\ \text { библ. } & - \text { библейский } \\ \text { в. } & - \text { век } \\ \text { дв. } & - \text { двойной } \\ \text { др.- евр. } & \text { - древне-еврейский } \\ \text { им. } & - \text { имя } \\ \text { именн. } & - \text { именник } \\ \text { лат. } & - \text { латышский } \\ \text { лит. } & - \text { литовский } \\ \text { нем. } & - \text { немецкий } \\ \text { польск. } & - \text { польский } \\ \text { ср. } & - \text { сравнить }\end{array}$

\section{Литература}

Блінец А. У., Клеицк. Старонкі даўняй гісторыі, Мінск 2011.

Лемцюгава В. П., Беларуская айканімія, Мінск 1970.

Лемцюгова В. П., Гісторыя анамастыкі, [w:] Stowiańska onomastyka. Encyklopedia, t. 1, E. Rzetelska-Feleszko, A. Cieślikowa (red.), Warszawa - Kraków 2002.

Лемцюгова В. П., Антрапанімія II - Прозвішчы, [w:] Słowiańska onomastyka, Encyklopedia, t. 1, E. Rzetelska-Feleszko, A. Cieślikowa (red.), Warszawa - Krakow 2002.

Бірыла М. В., Беларуская антрапанімія, t. 1-3, Мінск 1966-1982.

Бірыла М. В., Беларускія антрапанімічныя назвы у іх адносінах да антрапанімічных назвау іншых славянскіх моў, Мінск 1963.

29 В. А. Никонов, Словарь русских фамилий, Москва 1993, s. 199. 
Бірыла М. В., Тыппалогія і геаграбія славянскіх прозвішчаў, Мінск 1988.

Бунчук І. М., Крыўко М. Н., Тлумачальны слоўнік беларускай літаратурнай мовы, Мінск 2002.

Шур В., Беларускія улласныя імёны, Мінск 1998.

Ермолович Д. И., Имя собственное на стыке языков и культур, Москва 2001.

Историко-документальная хроника Клеикого района „Память”, М. С. Кусенков (red.), Минск 1999.

Кривицкий А. А., Подлужный А. И., Учебник белорусского языка, Минск 1994.

Лемтюгова В. П., Фамилия как привилегия, [w:] „Беларусь Сегодня”, № 180, www.familii.com. ua/new26.htm [dostęp: 28.10.2013].

Никонов В. А., Словарь русских фамилий, Москва 1993.

Петровский Н. А., Словарь русских тичных имён, Москва 1984.

Судник М. Р., Словарь тичных собственных имён, Минск 1965.

Суперанская А. В., Суслова А. В., О русских именах, Ленинград 1985.

Суперанская А. В., Суслова А. В., Современные русские фамилии, Москва 1981.

Унбегаун Б. О., Русские фамилии, Москва 1989.

Abramowicz Z., Antroponimia Żydów białostockich, Białystok 2010.

Abramowicz Z., Słownik etymologiczny nazwisk Żydów białostockich, Białystok 2003.

Kondratiuk M., Nazwiska pochodzenia bałtyckiego, cz. 1, „Acta Baltico-Slavica”, Warszawa 2000.

Rymut K., Nazwy rodzinne, rodowe i zbiorowe, [w:] Polskie nazwy własne. Encyklopedia, E. Rzetelska-Feleszko (red.), Warszawa - Kraków 2005.

Słownik białorusko-polski, T. Chylak-Schroeder, J. Głuszkowska-Babicka, T. Jasińska-Socha (red.), Warszawa 2012. 